\title{
PERFORMANCE OF AN ANAEROBIC BAFFLED REACTOR (ABR) IN TREATMENT OF CASSAVA WASTEWATER
}

\author{
Fernanda M. Ferraz ${ }^{1 *}$; Aline T. Bruni²; Vanildo L. Del Bianchi ${ }^{1}$ \\ ${ }^{1}$ Departamento de Engenharia e Tecnologia de Alimentos, Instituto de Biociências Letras e Ciências Exatas de \\ São José do Rio Preto, Universidade Estadual Paulista São Paulo, São José do Rio Preto, SP, Brasil; ${ }^{2}$ Departamento de Física, \\ Instituto de Biociências Letras e Ciências Exatas de São José do Rio Preto, Universidade Estadual Paulista, \\ São José do Rio Preto, SP, Brasil.
}

Submitted: January 18, 2008; Returned to authors for corrections: March 15, 2008; Approved: February 25, 2009.

\begin{abstract}
The performance of an anaerobic baffled reactor (ABR) was evaluated in the treatment of cassava wastewater, a pollutant residue. An ABR divided in four equal volume compartments (total volume $4 \mathrm{~L}$ ) and operated at $35^{\circ} \mathrm{C}$ was used in cassava wastewater treatment. Feed tank chemical oxygen demand (COD) was varied from 2000 to $7000 \mathrm{mg} \mathrm{L}^{-1}$ and it was evaluated the most appropriated hydraulic retention time (HRT) for the best performance on COD removal. The ABR was evaluated by analysis of COD (colorimetric method), $\mathrm{pH}$, turbidity, total and volatile solids, alkalinity and acidity. Principal component analysis (PCA) was carried to better understand data obtained. The system showed buffering ability as acidity decreased along compartments while alkalinity and $\mathrm{pH}$ values were increased. There was particulate material retention and COD removal varied from 83 to $92 \%$ for HRT of 3.5 days.
\end{abstract}

Key words: Anaerobic baffled reactor (ABR); Anaerobic digestion; Cassava wastewater; COD removal; Principal component analysis (PCA)

\section{INTRODUCTION}

In Brazil, agricultural activity related to cassava generates, from the harvest to industrial processing, about one million employment positions, a significant economic aspect to the country (11). On the other hand, industrial processing generates cassava wastewater, also named manipueira, a very pollutant residue which has a COD around $100 \mathrm{~g} \mathrm{~L}^{-1}(10)$.

To reduce the environmental impact, this study suggests anaerobic digestion for cassava wastewater treatment by the use of an anaerobic baffled reactor (ABR). Microorganisms involved in this biological process degradate organic matter in the following steps: hydrolysis, acidogenesis, acetogenesis and methanogenesis, resulting on $\mathrm{CO}_{2}$ and $\mathrm{CH}_{4}$ (14).

ABR was chosen for the treatment due to its many advantages cited in the literature (5) and also because it has been studied in the treatment of different wastewaters, but without significant information about its performance to cassava wastewater $(1,4,5,6,8,12,16,18,19,20,21,24,27,28)$.

Chemometrics methods have also been applied to environmental studies as a statistic tool $(9,13,15,17,23,26)$; however, there is not a significant amount of reports related to its application at studies dealing with ABR. The aim of this research is to investigate how chemometrics contributes to the knowledge of ABR performance in cassava wastewater treatment. To better understand this performance and the response associated with each point of sampling (influent, compartments and effluent), variables measured and feed tank COD variations were analyzed by principal component analysis (PCA). This chemometric technique was able to optimize data interpretation, assigning specific variables on influent, compartments and effluent samples. The main issue is to classify information, evidencing only the most important variables that contribute to results interpretation.

*Corresponding Author. Mailing address: Departamento de Engenharia e Tecnologia de Alimentos, Instituto de Biociências Letras e Ciências Exatas de São José do Rio Preto, Universidade Estadual Paulista Cep 15054-000, São Paulo, Brasil. E-mail: fernanda.m.ferraz@gmail.com 


\section{MATERIALS AND METHODS}

\section{The reactor}

The ABR was constructed with glass, showing dimensions of $10 \mathrm{~cm}$ wide, $10 \mathrm{~cm}$ high and $40 \mathrm{~cm}$ long, with a total volume of $4 \mathrm{~L}$, divided in four equal compartments, as shown in Fig. 1. The width was 2 and $8 \mathrm{~cm}$, respectively, to the downcomer and upcomer. During all the experiment, the reactor was operated at $35^{\circ} \mathrm{C}$ and a peristaltic pump was used to control influent flow rates.

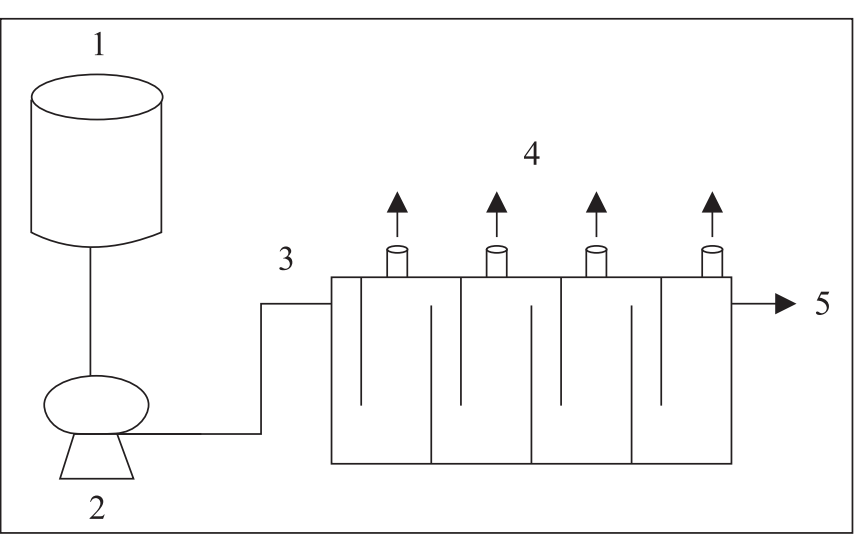

Figure 1. Scheme of the ABR. 1. Feed tank; 2. Peristaltic Pump; 3. Influent. 4. Sampling ports; 5. Effluent.

\section{The wastewater}

The cassava wastewater used came from a manioc flour industry, "Plaza-Indústria e Comércio Ltda", at Santa Maria da Serra, São Paulo, Brazil. This residue composition is basically starch, proteins, glucose, suspension of nitrogen matter and cyanidric acid (22).

\section{Seed Sludge}

The reactor was inoculated in $30 \%$ of its volume with granulated sludge from an UASB located at a drinking industry, Arco-Íris, installed at São José do Rio Preto, São Paulo, Brazil.

\section{The start-up period}

The start-up period was carried with feed tank COD around $2000 \mathrm{mg} \mathrm{L}^{-1}$ and hydraulic retention time (HRT) of 4 days. According to microorganisms adaptation, feed tank COD gradually increased to $7000 \mathrm{mg} \mathrm{L}^{-1}$, and it was evaluated the most appropriated HRT to the best efficiencies.

\section{Analysis}

ABR performance was evaluated by analysis of COD (colorimetric method), total and volatile solids, $\mathrm{pH}$ and turbidity, according to standard methods (2). Alkalinity and acidity were evaluated by a titrimetric method (25).

\section{Statistical Analysis}

Principal component analysis is a mathematical technique used to reduce the dimensions needed to accurately portray the characteristics of data matrices $(7,29)$. By means of this method the original matrix is represented by a set of new variables, called principal components. Each PC is constructed as a linear combination of variables:

$$
p_{i}=\sum_{j=1}^{v} c_{i, j} x_{j}
$$

where $p_{i}$ is the ith principal component and $c_{i, j}$ is the coefficient of the variable $x_{j}$. There are $v$ such variables. The first principal component PC1 is chosen in such a way that the new axis $p_{1}$ has the direction which maximizes the variance of data along that axis. The second and subsequent ones are chosen to be orthogonal to each other and account for the maximum variance in the data not yet accounted for by previous principal components.

PCA was performed on auto-escalated data organized in a matrix. The variables used were $\mathrm{pH}, \mathrm{COD}$, acidity, acidity/ alkalinity (RAc/Alk) ratio and HRT. Efficiencies for each point of sampling were also added at variables columns and the samples were divided in different classes according to the degree of efficiency: 1. low; 2. medium; 3. high.

\section{RESULTS AND DISCUSSIONS}

The results discussed are related to ABR performance along the experiment for organic loading rates (OLR) of 0.5, 1.4 and 2.0 g COD L $\mathrm{C}^{-1} \mathrm{~d}^{-1}$.

\section{Solids and COD}

Figs. 2 and 3 show organic matter stabilization as a function of time for total and volatile solids and COD removal, respectively. Solids analysis confirms that, since cassava wastewater is biodegradable, volatile solids are related to the organic fraction of this residue and represents about $70 \%$ of total solids.

At start-up period $\left(\mathrm{OLR} \approx 0.5 \mathrm{~g} \mathrm{COD} \mathrm{L}^{-1} \mathrm{~d}^{-1}\right)$, due to its high HRT (4 days) and pH adjustments, it could be observed COD removal of about $94 \%$ at the end of treatment. In ABR mainly acidogenic region, COD removal were $66 \%$ and $71 \%$ in the first and second compartments, respectively. A possible explanation is that $\mathrm{pH}$ adjustments might have favored methanogenic activity in these compartments. When these adjustments were interrupted and feed tank COD increased to $4000 \mathrm{mg} \mathrm{L}^{-1}$, the $\mathrm{pH}$ of these two first compartments was low and their COD removal dropped, indicating a predominance of acidogenesis over methanogenesis. 


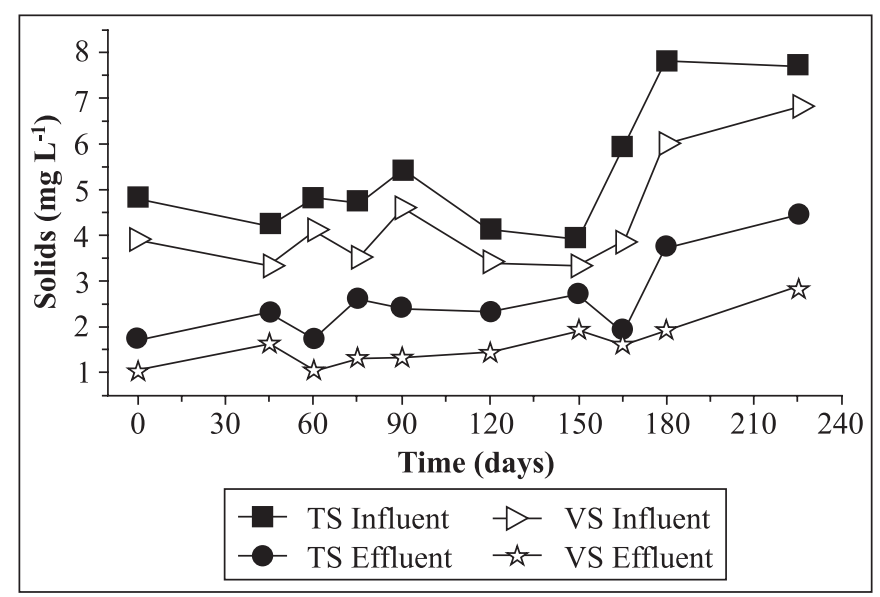

Figure 2. Total Solids (TS) and Volatile Solids (VS) behavior as a function of time.

In cases where HRT was 2.5 days, for a $4000 \mathrm{mg} \mathrm{L}^{-1}$ feed tank COD, ABR performance dropped strongly to $43 \%$, and to $46 \%$ for a $5000 \mathrm{mg} \mathrm{L}^{-1}$ feed tank COD. However, as described by previous studies $(20,21)$ the reactor exhibited ability to overcome this shock, recovering its optimal performances, as shown in Fig. 4. In these cases, HRT was increased again to 3.5 days and adjustments in feed tank $\mathrm{pH}$ were obtained using sodium bicarbonate.

As the system was stable and $\mathrm{pH}$ adjustments were not necessary, feed tank COD increased to $7000 \mathrm{mg} \mathrm{L}^{-1}$ and it was observed, for a 3.5 days HRT, an efficiency of $83 \%$ at the end of treatment $\left(\mathrm{OLR} \approx 2 \mathrm{~g} \mathrm{COD} \mathrm{L}^{-1} \mathrm{~d}^{-1}\right)$.

\section{pH}

Feed tank $\mathrm{pH}$ was adjusted with sodium bicarbonate at the start-up period and in cases where ABR performance strongly

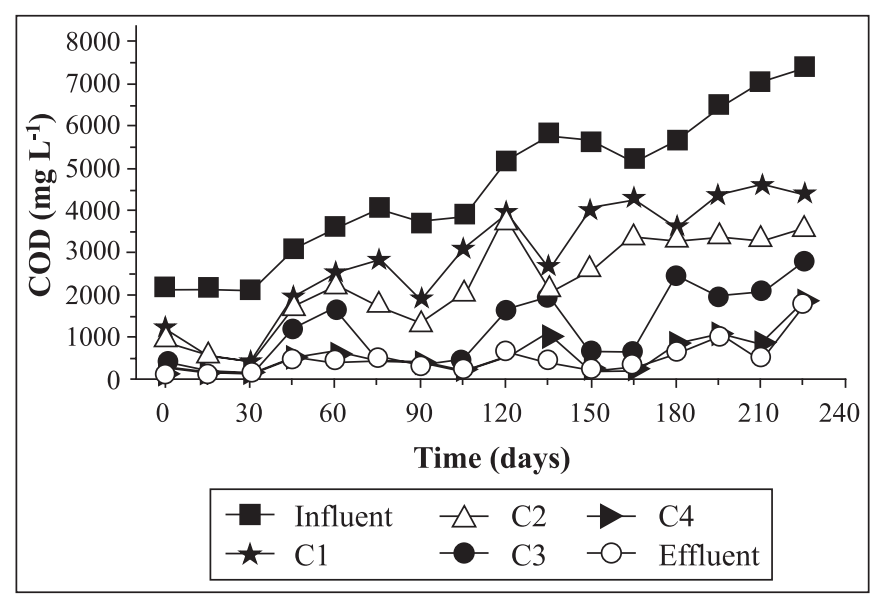

Figure 3. ABR performance as a function of time.
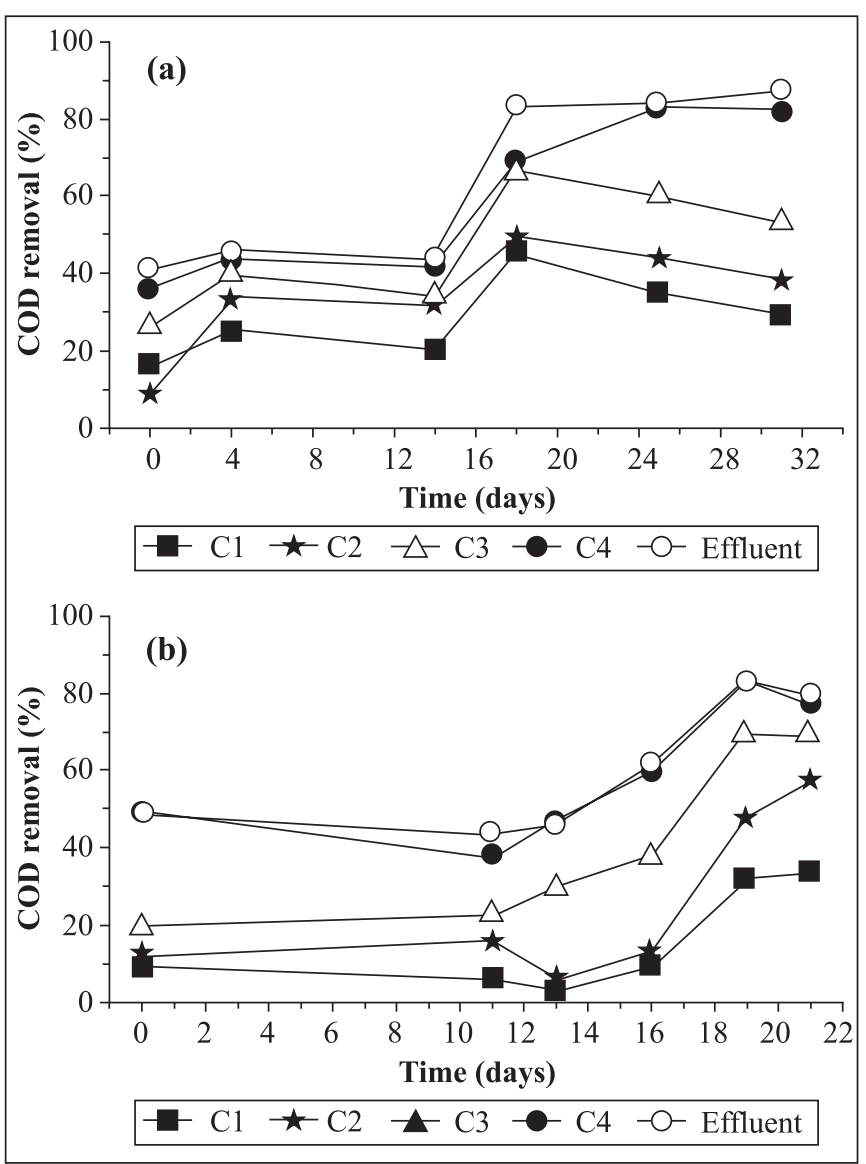

Figure 4. ABR recovery after a shock: (a) $4000 \mathrm{mg} \mathrm{COD} \mathrm{L}^{-1}$ and (b) $5000 \mathrm{mg} \mathrm{COD} \mathrm{L}^{-1}$.

decreased. In general, $\mathrm{pH}$ increased along the four compartments as the acids generated were consumed until the end of treatment, which indicates a possible buffering ability for ABR (Fig. 5).

\section{Acidity, Alkalinity and Turbidity}

Acidogenic groups are much more active in the first compartments, therefore, acidity is also higher compared to its values at the last compartment. On the other hand, alkalinity tends to be constant along the experiment, although its values are always major than acidity ones. This is better observed at the last compartments due to a higher methanogenic activity. Fig. 6 shows these two variables behavior as a function of time.

Turbidity varied significantly along compartments, however, generally decreased in the end of treatment, which means that ABR retains particulate material, as shown in Fig. 7.

\section{Chemometrics view}

According to PCA results, data were classified in three different classes which describe ABR efficiency. PC1 and PC2 
accounted $80 \%$ of whole system information. Scores plot (Fig. 8a) confirms COD removal profile along the treatment. Higher efficiencies (red points) are related to the fourth compartment

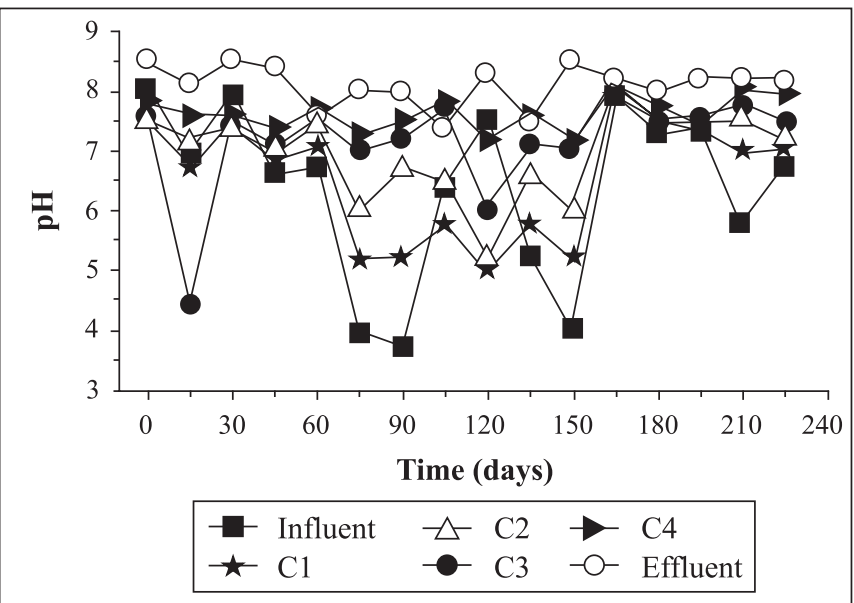

Figure 5. $\mathrm{pH}$ behavior as a function of time.

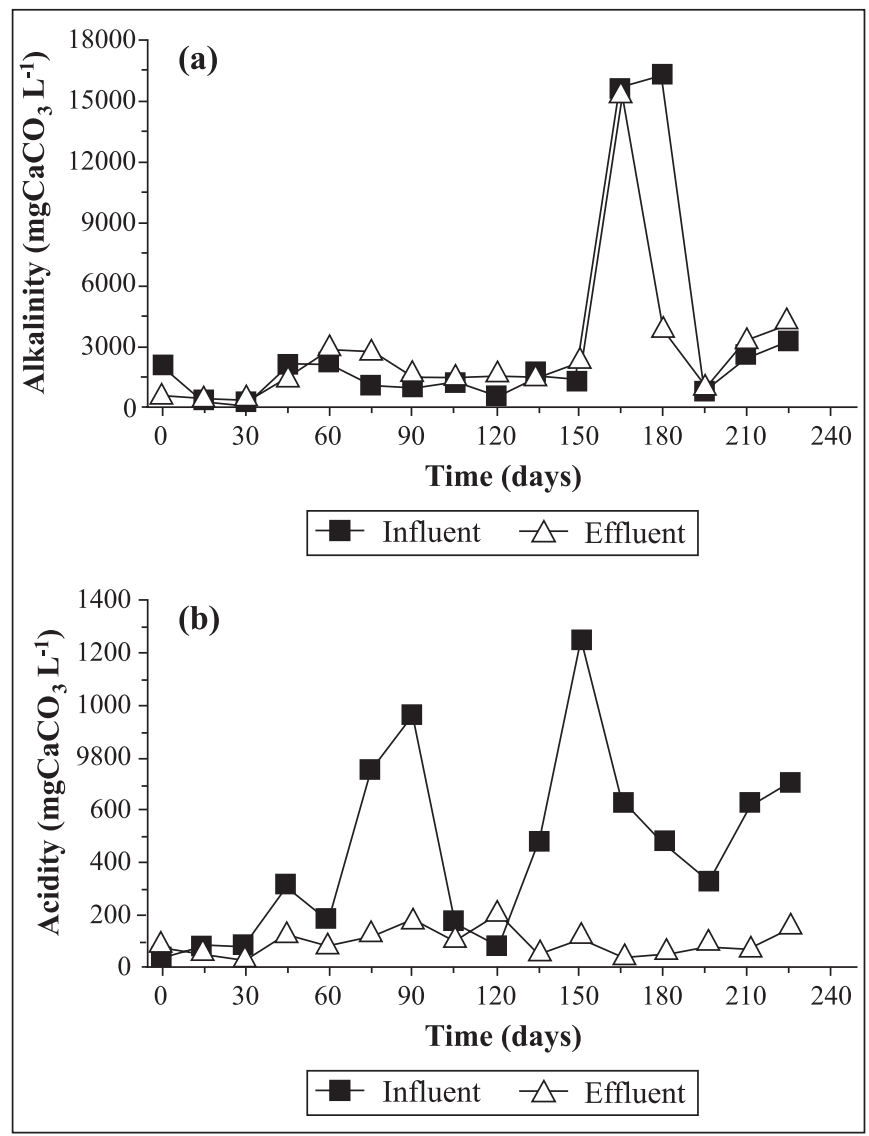

Figure 6. (a) Alkalinity and (b) acidity behavior as a function of time. and to effluent. An intermediate class (blue points) is observed for the third and second compartments due to methanogesis

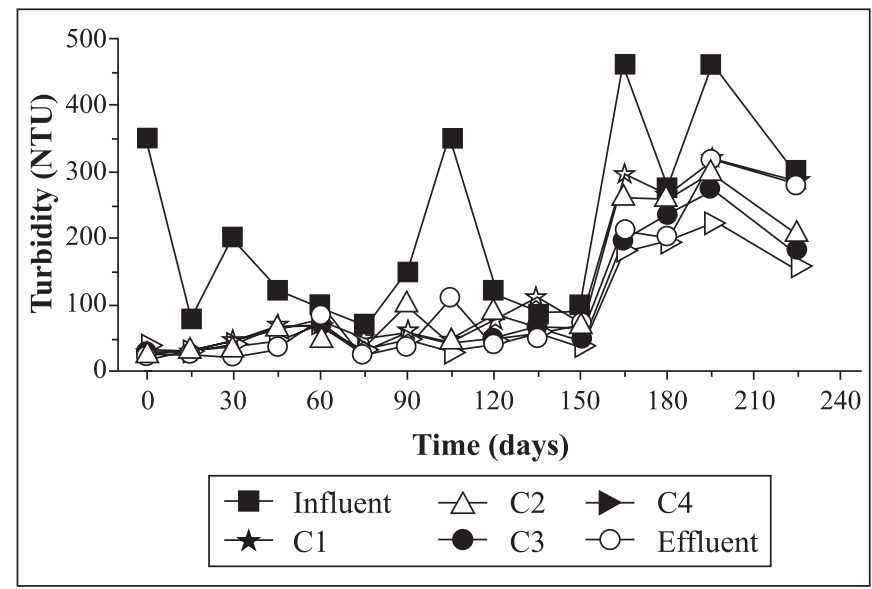

Figure 7. Turbidity behavior as a function of time.

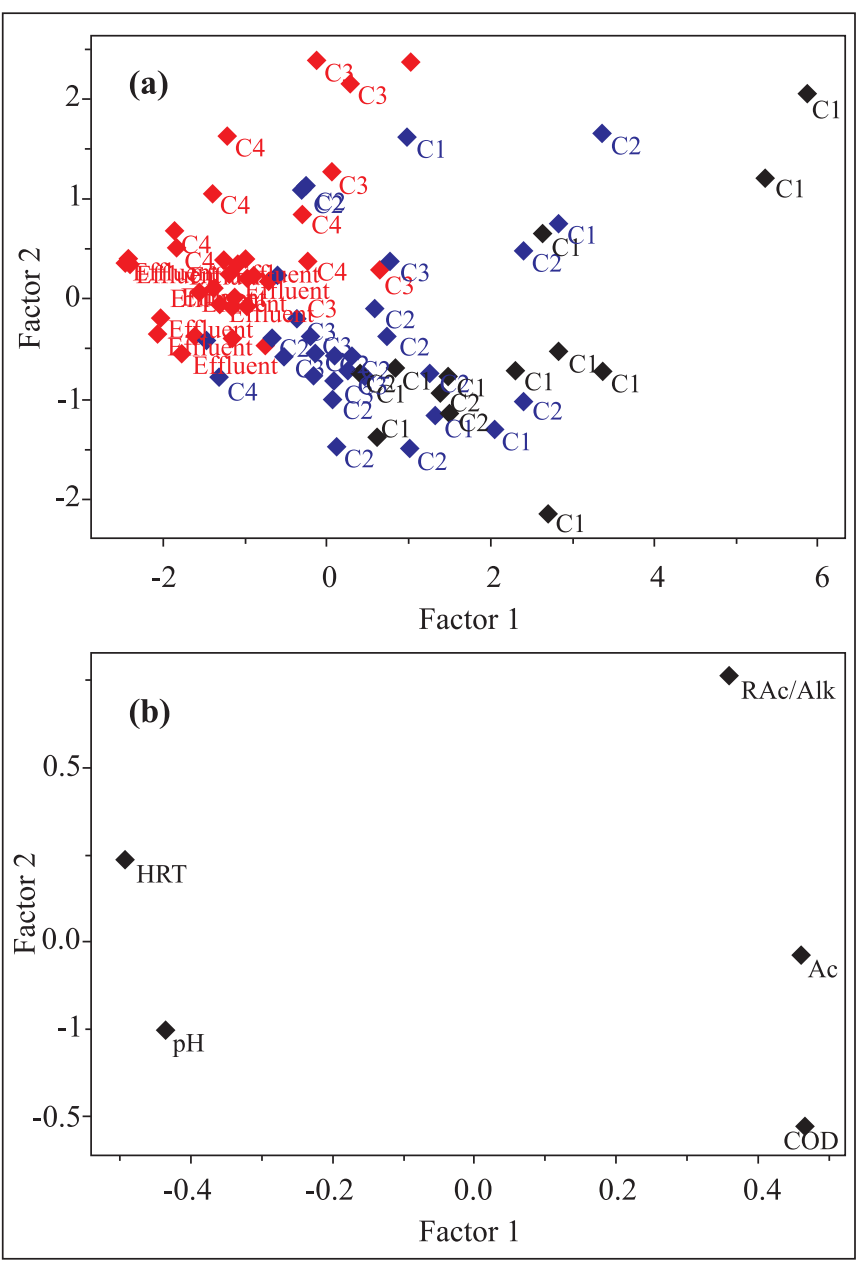

Figure 8. PCA plots: (a) scores and (b) loadings. 
activity; lower efficiencies (black points) mainly occur in the first compartment. As discussed before, the first compartments have the function of producing volatile organic acids, which are substrates for following steps of anaerobic digestion. It explains the lower efficiency for their class. As the residue flows along compartments, $\mathrm{COD}$ removal increases by $\mathrm{CO}_{2}$ and $\mathrm{CH}_{4}$ production. Loading plot (Fig. 8b) shows how chemical descriptors influence samples, classifying them as described above (high, medium and low efficiencies). PC1 and PC2 (or Factor 1 and Factor 2) are represented in terms of chemical descriptors by Equations $2 \mathrm{a}$ and $2 \mathrm{~b}$ and their coefficients demonstrate that all of them have similar load contributions on Factor 1 and Factor 2. Classes were separated along Factor 2 direction. According to Equation 2b, loadings indicate that RAc/ Alk and COD are the variables that most contribute to this component composition. This chemometric information is coherent with anaerobic digestion aspects, since RAc/Alk is related to methanogenic activity (responsible for the major COD removal) and COD, when its feed tank values are greater than $5000 \mathrm{mg} \mathrm{L}^{-1}$, it caused a decrease on the treatment efficiency.

$$
\begin{aligned}
\text { Factor } 1= & 0.47 \mathrm{COD}-0.49 \mathrm{HRT}+0.47 \mathrm{Ac}+ \\
& 0.36 \mathrm{RAc} / \mathrm{Alk}-0.43 \mathrm{pH} \\
\text { Factor } 2= & -0.54 \mathrm{COD}+0.24 \mathrm{HRT}-0.04 \mathrm{Ac}+ \\
& 0.76 \mathrm{RAc} / \mathrm{Alk}-0.25 \mathrm{pH}
\end{aligned}
$$

\section{CONCLUSION}

ABR was able to treat cassava wastewater removing $92 \%$ of organic matter, when feed tank COD varied from 2000 to $5000 \mathrm{mg}$ $\mathrm{L}^{-1}$ and HRT of 3.5 days. However, for the same HRT, the efficiency dropped to $83 \%$ when feed tank COD was $7000 \mathrm{mg} \mathrm{L}^{-1}$.

All variables of ABR performance evaluation were analyzed at once using chemometrics, which improves results interpretation. PCA was successfully applied at this study and seems to be a promising tool to support researches on wastewater treatment by ABR.

\section{ACKNOWLEDGEMENT}

The authors are grateful to Vitor B.P. Leite for helpful comments. FMF was supported by Fundação de Amparo à Pesquisa do Estado de São Paulo (FAPESP), Brazil.

\section{RESUMO}

\section{Desempenho de um Reator Anaeróbio Compartimentado (RAC) no tratamento da manipueira}

O desempenho de um reator anaeróbio compartimentado (RAC) foi avaliado para o tratamento da manipueira, resíduo tóxico. Um RAC dividido em quatro compartimentos de mesmo volume (volume total $4 \mathrm{~L}$ ) e operado a $35^{\circ} \mathrm{C}$ foi utilizado no tratamento da manipueira. A demanda química de oxigênio (DQO) do tanque de alimentação variou de 2000 a $7000 \mathrm{mg} \mathrm{L}^{-1}$ e avaliouse o tempo de residência hidráulica (TRH) mais apropriado ao melhor desempenho do reator. O RAC foi avaliado pelas análises de DQO (método colorimétrico), $\mathrm{pH}$, turbidez, sólidos totais e voláteis, alcalinidade e acidez. A Análise das Componentes Principais (PCA) foi conduzida para melhor compreensão dos dados obtidos. O sistema apresentou capacidade tamponante conforme a acidez decresceu ao longo dos compartimentos ao passo que a alcalinidade e o pH aumentaram. Houve retenção do material particulado e a remoção da DQO variou de 83 a $92 \%$ para TRH de 3,5 dias.

Palavras-chave: Reator Anaeróbio Compartimentado (RAC); Digestão anaeróbia; Manipueira; Remoção da DQO; Análise das Componentes Principais (PCA)

\section{REFERENCES}

1. Amirfakhri, J.; Vossoughi, M.; Soltanieh, M. (2006). Assessment of desulfurization of natural gas by chemoautotrophic bacteria in an anaerobic baffled reactor (ABR). Chem. Eng. Process., 45: 32-237.

2. APHA. (1995). Standard methods for the examination of water and wastewater. 19th ed. American Public Health Association, Washington, p. 1325.

3. Aquino, S.; Chernicharo, C.A.L. (2005). Build up of volatile fatty acids (VFA) in anaerobic reactors under stress conditions: causes and control strategies. Engenharia Sanitária Ambiental, 10: 152-161.

4. Bachmann, A.; Beard, V.L.; McCarty, P.L. (1985). Performance characteristics of the anaerobic baffled reactor. Water Res., 19: 99106.

5. Barber, W.P.; Stuckey, D.C. (1999). The use of the anaerobic baffled reactors $(\mathrm{ABR})$ for wastewater treatment: A review. Water Res., 33: 1559-1578.

6. Barber, W.P.; Stuckey, D.C. (2000a). Nitrogen removal in a modified anaerobic baffled reactor (ABR): 1, Denitrification. Water Res., 34: 2413-2422.

7. Beebe, K.R.; Pell, R.J.; Seasholtz, M.B. (1998). Chemometrics: A Practical Guide. John Wiley \& Sons, New York, 360p.

8. Boopathy, R. (1998). Biological treatment of swine waste using anaerobic baffled reactors. Bioresour. Technol., 64: 1-6.

9. Brodnjak-Vonèina, D.; Dobènik, D.; Noviè, M.; Zupan, J. (2002). Chemometrics characterization of the quality of river water. Anal. Chim. Acta, 462: 87-100.

10. Del Bianchi, V.L.; Cereda, M.P. (2000). Balanço de massa de uma fábrica de farinha de mandioca de médio porte do estado de São Paulo. Revista Energia na Agricultura, 14: 38-44.

11. EMBRAPA. Available at: http://sistemasdeproducao.cnptia.embrapa.br/ FontesHTML/Mandioca/mandioca_semiarido/importancia.htm

12. Faisal, M.; Unno, H. (2001). Kinetic analysis of palm oil mill wastewater treatment by a modified anaerobic baffled reactor. Biochem. Eng. J., 9: 25-31, 2001.

13. Ferreira, M.M.C.; Faria, C.G.F.; Paes, E.T. (1999). Oceanographic characterization of northern Sao Paulo Coast: a chemometric study. Chemometrics and Intelligent Laboratory Systems, 47: 289-297.

14. Foresti, E.; Florêncio, L.; Van Haandel, A.; Zaiat, M.; Cavalcanti, P.F.F. (1999). Tratamento de esgotos sanitários por processo 
anaeróbio e disposição controlada no solo, In: Fundamentos do tratamento anaeróbio. PROSAB, Rio de Janeiro, p. 29-51.

15. Gonçalves, F.L.T.; Carvalho, L.M.V.; Conde, F.C.; Latorre, M.R.D.O.; Saldivac, P.H.N.; Bragab, A.L.F. (2005). The effects of air pollution and Meteorological parameters on respiratory morbidity during the summer in Sao Paulo City. Environ. Int., 31: 343-349.

16. Grover, R.; Marwaha, S.S.; Kennedy, J.F. (1999). Studies on the use of an anaerobic baffled reactor for the continuous anaerobic digestion of pulp and paper mill black liquors. Process Biochem., 34: 653657.

17. Kowalkowski, T.; Zbytniewski, R.; Szpejna, J.; Buszewski, B. (2006). Application of chemometrics in river water classification. Water Res., 40: 744-752.

18. Kusçu, O.S.; Sponza, D.T. (2005). Performance of anaerobic baffled reactor (ABR) treating synthetic wastewater containing pnitrophenol. Enzyme Microb. Technol., 36: 888-895.

19. Langenhoff, A.A.M.; Intrachandra, N.; Stuckey, D.C. (2000). Treatment of dilute soluble and colloidal wastewater using an anaerobic baffled reactor: influence of hydraulic retention time. Water Res., 34: 1307-2000.

20. Nachaiayasit, S.; Stuckey, D.C. (1997a). The effect of shock loads on the performance of an anaerobic baffled reactor (ABR).1. Step changes in feed concentration at constant retention time. Water Res., 31: 2737-2746.
21. Nachaiayasit, S.; Stuckey, D.C. (1997b). The effect of shock loads on the performance of an anaerobic baffled reactor (ABR).2. Step and transient hydraulic shocks at constant feed strength. Water Res., 31: 2747-2754.

22. Pawlowsky, U. (1991). Curso de tratamento de efluentes industriais: industrialização da mandioca. Toledo.

23. Santamaria-Fernandez, R.; Cave, M.R.; Hill, S.J. (2006). Trace metal distribution in the Arosa estuary (N.W. Spain): The application of a recently developed sequential extraction procedure for metal partitioning. Anal. Chim. Acta, 557: 344-352.

24. She, Z.; Zheng, X.; Yang, B.; Jin, C.; Gao, M. (2006). Granule development and performance in sucrose fed anaerobic baffled reactors. J. Biotechnol., 122: 198-208.

25. Silva, M.O.S.A. (1977). Análises físico-químicas para controle de estações de tratamento de esgoto. CETESB, São Paulo.

26. Stanimirova, I.; Walczak, B.; Massart, D.L. (2005). Multiple factor analysis in environmental chemistry. Anal. Chim. Acta, 545: 1-12.

27. Uyanik, S.; Sallis, P.J.; Anderson, G.K. (2002). The effect of polymer addition on granulation in an anaerobic baffled reactor (ABR). Part I: process performance. Water Res., 36: 933-943.

28. Vossoughi, M.; Shakeri, M.; Alemzadeh, I. (2003). Performance of anaerobic baffled reactor treating synthetic wastewater influenced by decreasing $\mathrm{COD} / \mathrm{SO}_{4}$ ratios. Chem. Eng. Process., 42: 811-816.

29. Wold, S.; Esbensen, K.; Geladi, P. (1987). Principal component analysis. Chemometrics and Intelligent Laboratory Systems, 2: 37-52. 